\title{
Improving Shear Strength Parameters of Sandy Soil using Enzyme-Mediated Calcite Precipitation Technique
}

\author{
Putra, H. ${ }^{* *}$, Yasuhara, H. ${ }^{2}$, Kinoshita, N. ${ }^{2}$ Erizal $^{1}$ and Sudibyo, T. ${ }^{1}$
}

\begin{abstract}
Several methods have been established for their various potential applications as soil improvement technique, and recently the application of grouting technique using biological process have been proposed. This study discussed the applicability of enzyme-mediated calcite precipitation (EMCP) in improving the shear strength parameters of sandy soil. In this study, soil specimens were prepared and treated with the grouting solutions composed of urea, calcium chloride, magnesium sulfate and enzyme of urease. Evolutions in the cohesion and internal friction angle of the improved soil were examined through the direct shear tests. The presence of the precipitated materials, comprising 4.1 percent of the soil mass of the treated sand, generated a cohesion of $53 \mathrm{kPa}$. However, contrary to the improvement of cohesion, the friction angle is relatively constant. It indicated that the application of the EMCP technique has no significant impact on the friction angle.
\end{abstract}

Keywords: EMCP; shear strength; cohesion; internal friction; direct shear; UCS.

\section{Introduction}

Several methods have been established for their various potential applications as soil improvement technique, such as the application of waste product, natural. and synthetic materials [1-5] and the injection of grouting material or deep mixing $[1,6]$. The application of grouting technique using biological process have been recently proposed, which have been made possible through interdisciplinary research at the confluence of microbiology, geochemistry, and geotechnical engineering. The chemical material is the most commonly used in soil improvement method $[1,7]$. One of the emerging and promising biochemical soil improvement methods is bio-cementation which is called calcite induced precipitation method (CIPM) [8-11].

Calcite induced precipitation method (CIPM) has been studied extensively for its potential as a soil improvement technique. It can significantly improve the shear strength and stiffness [8,9,12-14] and can reduce the permeability of the sandy soil $[9,10,15]$. The improvement in compressive strength ranging from 0.40 MPa to $12 \mathrm{MPa}$ depending upon the mass of precipitated minerals, were achieved in the previous studies [16].

\footnotetext{
1 Department of Civil and Environmental Engineering, Bogor Agricultural University, Darmaga, Bogor, 16680, INDONESIA.

2 Department of Civil and Environmental Engineering, Ehime University, 3 Bunkyo-cho, Matsuyama, 790-8577, JAPAN.

* Corresponding author: heriansyahptr@apps.ipb.ac.id

Note: Discussion is expected before November, $1^{\text {st }} 2018$, and will be published in the "Civil Engineering Dimension", volume 21, number 1, March 2019.
}

Received 11 June 2018; revised 19 July 2018; accepted 20 September 2018
Many of the studies have used microorganism (e.g., Sporosarcina pasteurii) to hydrolyze urea into ammonium $\left(\mathrm{NH}_{4}{ }^{+}\right)$and carbonate ions $\left(\mathrm{CO}_{3}{ }^{2}\right)$ $[8,9,17]$. The produced carbonate ions are precipitated as calcite crystals in the presence of calcium ions. The reactions of the urea hydrolysis and the calcite formation are shown in Equations (1) - (3):

$$
\begin{aligned}
& \mathrm{CO}\left(\mathrm{NH}_{2}\right)_{2}+2 \mathrm{H}_{2} \mathrm{O} \stackrel{\text { urease }}{\longrightarrow} 2 \mathrm{NH}_{4}^{+}+\mathrm{CO}_{3}^{2-} \\
& \mathrm{CaCl}_{2} \rightarrow \mathrm{Ca}^{2+}+2 \mathrm{Cl}^{-} \\
& \mathrm{Ca}^{2+}+\mathrm{CO}_{3}^{2-} \rightarrow \mathrm{CaCO}_{3} \downarrow \text { (precipitated) }
\end{aligned}
$$

The grouting solution composed of urea, $\mathrm{CaCl}_{2}$ and a bio-catalytic agent (e.g., bacterial cell), which produces calcite crystals, is injected into the sandy soil. The precipitated calcium carbonate in the soil may provide bridges between the grains of sand, restricting their movement, and thus, improving the strength and stiffness of the sandy soil [10]. The deposited calcite fills the voids, thereby reducing the porosity and hence decreasing the permeability $[10,18]$. However, there are some difficulties related to the utilization of a bacteria cell in the calcite precipitation technique $[16,19,20]$. For example, the incubation of bacteria may be difficult to control, because it requires, special treatments [19]. In addition, the high concentration of reagents (i.e. urea and $\mathrm{CaCl}_{2}$ ) may have an inhibitory effect on the growth rate of bacteria [21], and hence, the activity of bacteria may be limited within the soil $[16,20]$.

An alternative method among calcite precipitation techniques, which is called enzyme-mediated calcite precipitation (EMCP) has been investigated in the previous studies $[12,18,19]$. In this technique, the enzyme of urease itself is utilized to dissociate urea into ammonium and carbonate ions, instead of bacteria. A schematic of the precipitation process and the expected of improving mechanism are illustrated 
in Figure 1 [18,22]. The efficacy of the EMCP technique as soil improvement method has already been assessed in the previous studies [11,18,19,23], unconfined compressive strength, ranging from 200 $\mathrm{kPa}$ to $1.6 \mathrm{MPa}$, were achieved.
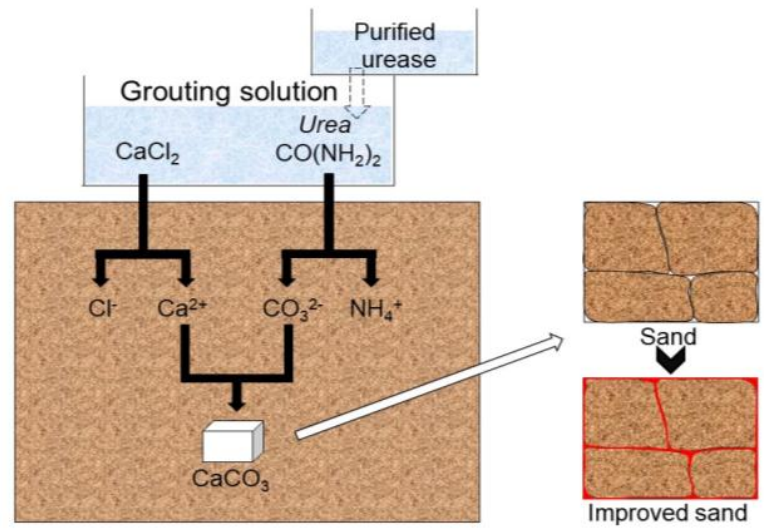

Figure 1. Schematic of Precipitation Process and Grouting Mechanism [18,22]

Many of those studies were using unconfined strength (UCS) tests to evaluate the improvement in the strength of treated soil $[9,10,19]$. The result of the UCS test provides the strength of the soil as the effect of cohesion only. The formulation of cohesion in UCS tests are shown in Equations (4)-(5).

$\mathrm{c}=\mathrm{s}=\frac{q u}{2}$
$q u=\frac{P_{\max }}{A}$

Where, $s$ is shear strength, $c$ is cohesion, $q u$ is compressive strength, $P_{\max }$ is the maximum load at failure, and $A$ is an area of the sample. As is apparent in the Equations (4) and (5), the cohesion is equal with the shear strength, which is calculated from the compressive strength. Meanwhile, the sandy soil also has friction angle as its major strength parameter. Hence, the study about the impact of EMCP technique on cohesion and friction angle is crucial because it provides a deeper understanding of EMCP technique and its mechanism in improving the shear strength of soil. In this study, the direct shear tests were conducted to evaluate the effect of grouting solution of EMCP on the cohesion and friction angle. The selected grouting material was fixed by precipitation test in our previous study, and then it was utilized to improve the strength of sandy soil. Finally, by comparing the shear parameters treated soil obtained in this study and those obtained from the literature, the impact of grouting solution of EMCP on both shear parameters was explicitly investigated.

\section{Materials and Methods}

\section{Sand Sample}

Silica sand which was classified as poorly graded sand (SP) based on the unified soil classification system (USCS) [16] is used in this study. The physical properties and the curve of the grain size distribution of the sand utilized in this work are shown in Table 1 and Figure 2 [13,24].

Table 1. Physical Properties of Sand [13,24]

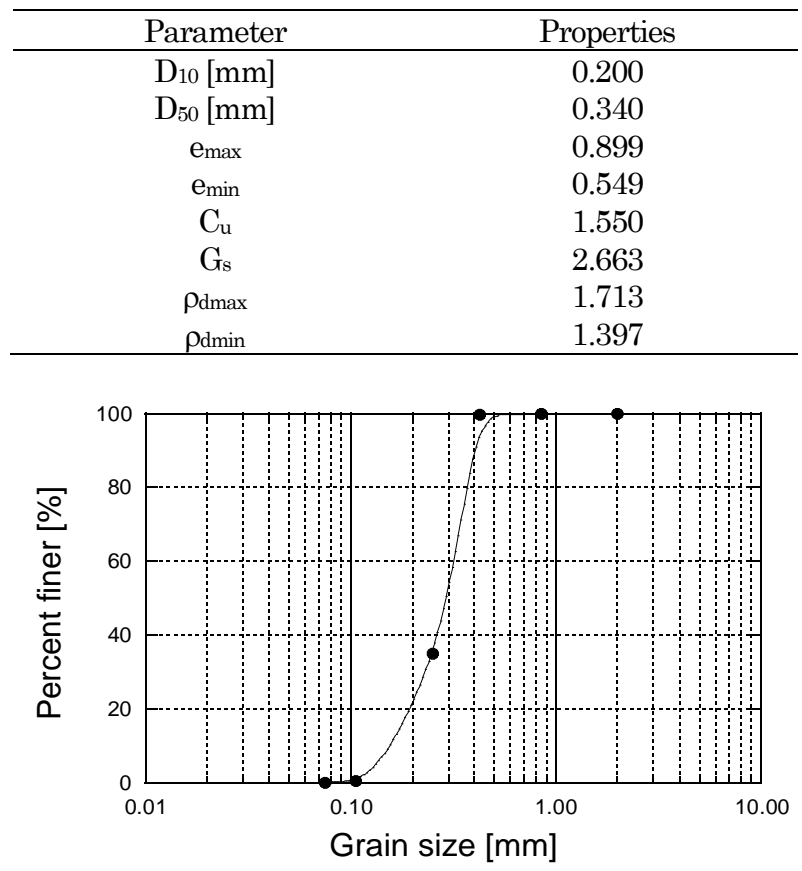

Figure 2. Particle Size Distribution of the Sandy Soil [13,24]

\section{Grouting Materials}

The precipitated amount corresponding to the different combinations of $\mathrm{CaCl}_{2}-\mathrm{MgSO}_{4}$ have been evaluated in our previous work. The precipitation of the minerals was directly assessed in transparent test tubes. The total concentration of $\mathrm{CaCl}_{2}-\mathrm{MgSO}_{4}$ was fixed at $1.00 \mathrm{~mol} / \mathrm{L}$. The concentrations of $\mathrm{MgSO}_{4}$, varying from 0.02 to $0.10 \mathrm{~mol} / \mathrm{L}$, were added to obtain the optimum combination based on the amount of precipitated minerals. Urease of $2.00 \mathrm{~g} / \mathrm{L}$ was utilized to dissociate $1.00 \mathrm{~mol} / \mathrm{L}$ of urea. The conditions for the test tube experiments are listed in Table 2 [25].

Table 2. Experimental Condition for Precipitation Tests [25]

\begin{tabular}{ccccc}
\hline Case & $\begin{array}{c}\text { Conc. of } \\
\text { enzyme } \\
\text { urease }\end{array}$ & $\begin{array}{c}\text { Conc. of } \\
\text { Urea }\end{array}$ & $\begin{array}{c}\text { Conc. of } \\
\text { CaCl2 }\end{array}$ & $\begin{array}{c}\text { Conc. of } \\
\text { MgSO4 }\end{array}$ \\
\cline { 2 - 5 }$[\mathrm{g} / \mathrm{L}]$ & {$[\mathrm{mol} / \mathrm{L}]$} & {$[\mathrm{mol} / \mathrm{L}]$} & {$[\mathrm{mol} / \mathrm{L}]$} \\
\hline S0 & 2.00 & 1.00 & 1.00 & 0.00 \\
S1 & 2.00 & 1.00 & 0.98 & 0.02 \\
S2 & 2.00 & 1.00 & 0.96 & 0.04 \\
S3 & 2.00 & 1.00 & 0.94 & 0.06 \\
S4 & 2.00 & 1.00 & 0.92 & 0.08 \\
S5 & 2.00 & 1.00 & 0,90 & 0.10 \\
\hline
\end{tabular}

Test tube experiments were performed directly to evaluate the mass of precipitated materials. The 
experimental procedures developed by Neupane et al. [19] were adopted in this work. Urease with concentrations of $2.00 \mathrm{~g} / \mathrm{L}$ and distilled water were mixed separately. The mixed solutions were stirred for 2 minutes and then filtered through filter paper (pore size (PS) of $11 \mu \mathrm{m}$ ) to remove the undissolved particles. The urea and combinations of $\mathrm{CaCl}_{2}$ $\mathrm{MgSO}_{4}$, with a concentration of $1.0 \mathrm{~mol} / \mathrm{L}$, were also mixed with distilled water, respectively. The filtered urease, urea, and combinations of $\mathrm{CaCl}_{2}-\mathrm{MgSO}_{4}$ solutions were mixed thoroughly in a test tube, to obtain a volume of $30 \mathrm{~mL}$, and then allowed to react for an entire three day curing times. Test-tube samples were kept in a box without shaking at a room temperature of $20^{\circ} \mathrm{C}$. After the 3 days-curing time, the grouting solution was filtered through filter paper, and thus, the retained particles on the filter paper and the remained particles in the tubes were dried. Then the total mass of the precipitated minerals was evaluated by combining the precipitated calcite deposited in the test tubes with the minerals remaining on the filter paper [19].

A summary of the results of test tube experiments for the several combinations of $\mathrm{MgSO}_{4}$ and $\mathrm{CaCl}_{2}$ is depicted in Figure 3 [25]. The enzyme of urease of $2.0 \mathrm{~g} / \mathrm{L}$ is used to hydrolyze $1.0 \mathrm{~mol} / \mathrm{L}$ of urea.

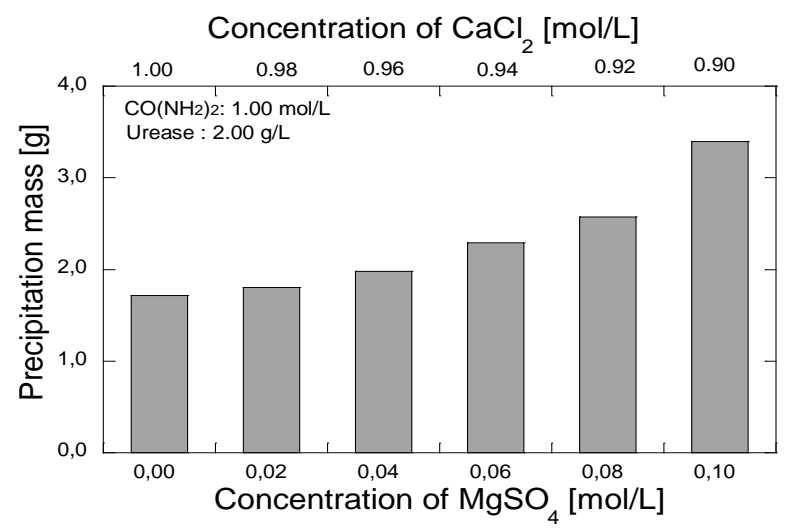

Figure 3. Precipitated Mass in Various Combinations of $\mathrm{CaC}_{2}-\mathrm{MgSO}_{4}[25]$

As apparent, the precipitated mass gradually increased as the concentration of $\mathrm{MgSO}_{4}$ was increased. However, the presence of a high concentration of magnesium sulfate in the grouting solution increased the reaction rate [25]. The precipitation occurred quickly after mixing, and the precipitated materials might have formed before all of the grouting solutions had been passed through the sand samples. The precipitated calcite was concentrated in the upper side of the sand samples. This may have hampered the permeation of the injecting solution between the soil particles [25]. Hence, in order to evaluate the impact of the EMCP technique on shear strength parameters, the combination of $\mathrm{CaCl}_{2}$ and $\mathrm{MgSO}_{4}$ of 0.96 and $0.04 \mathrm{~mol} / \mathrm{L}$, respectively, were used in this work.

\section{Shear Strength Analysis}

In order to investigate the effect of the presence of the precipitated materials on the shear strength parameters (i.e., cohesion and friction angle) of treated sand, the direct shear tests are conducted. The sample preparation procedures developed by Putra et al. [26] were followed in this work. The silica sand was poured into the shear box to obtain a relative density of $50 \%$. The fixed mass of sand is prepared and poured into the shear box using the funnel. The distance between the outlet of the funnel and the surface of the sand sample inside the shear box is controlled to obtain the homogenous density of the sand sample

Then, the selected grouting material is injected into the soil samples from the top. The treated samples were cured at a room temperature of $20^{\circ} \mathrm{C}$ during 3 days curing time. Then, the tests were performed. The direct shear test was also performed for untreated sandy soil. The ASTM standard procedure for the direct shear test [27] was followed in this study. The normal stress of $0.80,1.60$ and 3.20 $\mathrm{kN} / \mathrm{cm}^{2}$ were applied to provide the relation between normal stress and shear stress for each condition. The tests were performed under wet conditions to avoid any unexpected precipitation that may occur when samples are intentionally dried out. Two identical experiments were conducted for each condition to check the reproducibility. The experimental conditions for the direct shear tests are shown in Table 3.

Table 3. Experimental Conditions for Direct Shear Tests

\begin{tabular}{|c|c|c|c|c|c|c|c|c|}
\hline \multirow[t]{2}{*}{ Case } & \multirow[t]{2}{*}{$\begin{array}{c}\text { Sand } \\
\text { condition }\end{array}$} & \multicolumn{4}{|c|}{ Grouting Material } & \multicolumn{3}{|c|}{$\begin{array}{l}\text { Normal stress } \\
\left(\mathrm{kN} / \mathrm{cm}^{2}\right)\end{array}$} \\
\hline & & $\begin{array}{c}\mathrm{CaCl}_{2} \\
(\mathrm{~mol} / \mathrm{L})\end{array}$ & $\begin{array}{l}\mathrm{MgSO}_{4} \\
(\mathrm{~mol} / \mathrm{L})\end{array}$ & $\begin{array}{c}\text { Urea } \\
(\mathrm{mol} / \mathrm{L})\end{array}$ & $\begin{array}{c}\text { Urease } \\
(\mathrm{g} / \mathrm{L})\end{array}$ & $\sigma_{1}$ & $\sigma_{2}$ & $\sigma_{3}$ \\
\hline$\overline{\mathrm{DS}-0}$ & Un- & - & - & - & - & 0.80 & 1.60 & 3.20 \\
\hline DS-1 & $\begin{array}{l}\text { treated } \\
\text { sand } \\
\text { Treated } \\
\text { sand }\end{array}$ & 0.96 & 0.04 & 1.0 & 2.0 & 0.80 & 1.60 & 3.20 \\
\hline
\end{tabular}

The acid leaching method with a percentage error of $1.8 \%$ [26] was conducted to evaluate the precipitated mass within the sandy soil. Treated sand of $50 \mathrm{~g}$ was collected from each part, washed with distilled water to dissolve the product of $\mathrm{NH}_{4} \mathrm{Cl}$, and dried in an oven for $24 \mathrm{hr}$. The dried sand was weighed and washed with $0.1 \mathrm{~mol} / \mathrm{L}$ of $\mathrm{HCl}$ several times until air bubbles no longer appeared. The sample was dried again, and the final weight was taken. The dry weight lost during the acid leaching was evaluated and was assumed to be the weight of the mineral mass [26].

\section{Results}

The results of direct shear tests are depicted in Figure 4. As is apparent, the injection of grouting 
material into the sand sample brings about significant improvement on the cohesion of the treated sand. A cohesion of $53 \mathrm{kPa}$ was achieved in presence of precipitated calcite within the sandy soil. However, the precipitated materials have no significant impact on the friction angle. Friction angle obtained from the treated sand is 18.50 . Comparison to the friction angle of untreated sand, the presence of precipitated material within sandy soil result in the relative similar friction angle.

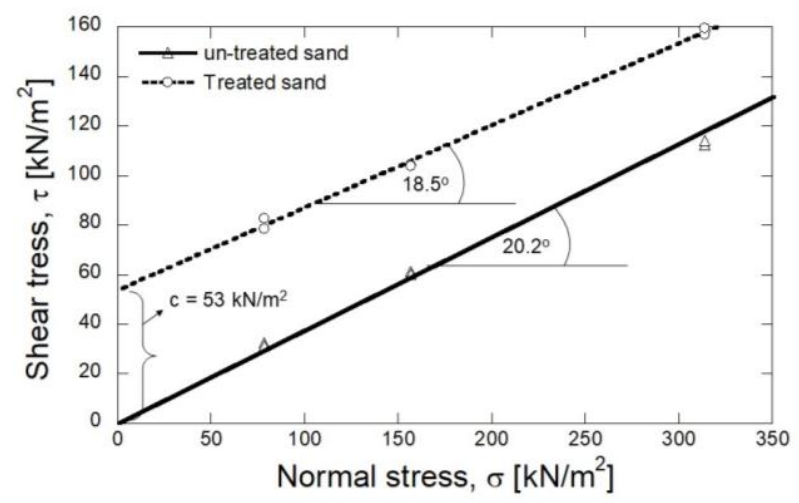

Figure 4. Shear Stress-normal Stress Curve and Shear Strength Parameters

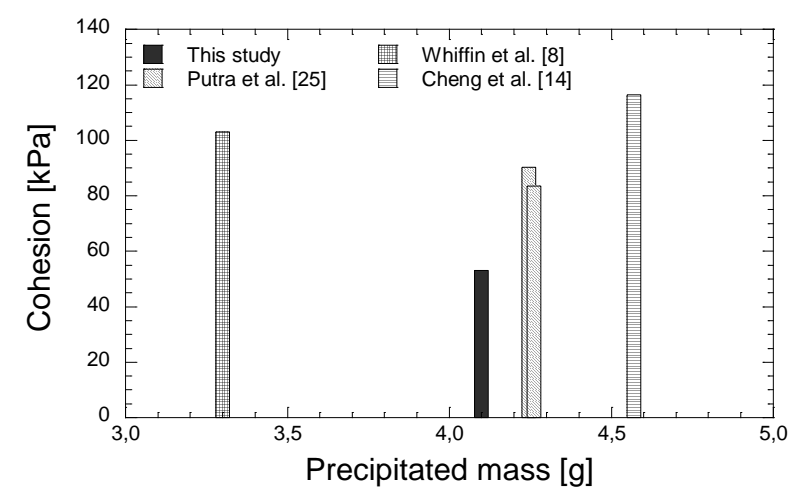

Figure 5. The Relation between Precipitated Mass and Cohesion

The relation between cohesion and precipitated mass within the sand samples are depicted in Figure 5. As is apparent, the presence of precipitated material of $4.10 \%$ of the soil mass attributes to the cohesion of 53 $\mathrm{kPa}$. In comparison to the previous studies [8,14,25], in which effects of EMCP on the shear strength parameters were evaluated using UCS tests, in the relative similar precipitated mass, the cohesion obtained in this study was relatively lower than those derived from the previous studies. Putra et al. [25] and Whiffin et al. [8] have evaluated the improvement on the strength of the sandy soil treated by calcite precipitation technique. The improvement in compressive strength up to $600 \mathrm{MPa}$ depending upon the mass of precipitated minerals was achieved $[8,25]$. The cohesion of $100 \mathrm{kPa}$ and $90 \mathrm{kPa}$ from the precipitated mass of $3.30 \%$ and $4.20 \%$, respectively
[8,25] were obtained. In addition, Cheng et al. [14] also obtained a cohesion of $120 \mathrm{kPa}$ from $4.6 \%$ of precipitated calcite [14]. These show that the cohesion derived from the UCS test results relatively higher than the cohesion evaluated from the direct shear test. This indicated that the friction angle also has the contribution on the strength. Hence, the obtained strength from UCS test, which ignores the input of the friction angle may not be accurate enough to estimate the cohesion of the treated sand.

\section{Conclusions}

The effects of the application of enzyme-mediated calcite precipitation on shear strength parameters of the sandy soil have been evaluated. The grouting material of EMCP composed of calcium chloride, urea, magnesium sulfate and enzyme of urease was injected into the prepared sandy soil. The evolution of cohesion and friction angle was evaluated through direct shear tests. The precipitated mass within sandy soil was also investigated using acid leaching method. The presence of precipitated material within the sandy soil, which is produced by grouting solution of EMCP brought about a significant effect on the improvement of cohesion. A cohesion of 53 $\mathrm{kPa}$ was provided by the precipitated material of $4.1 \%$ of the soil mass. However, application of precipitated material has no the significant impact on the friction angle. A relative similar friction angle was obtained in the treated and untreated sandy soil.

\section{Acknowledgments}

This work has been partly supported by a research grant from the Penta-Ocean Constructions Co. Ltd. Their support is gratefully acknowledged.

\section{References}

1. Mujah, D., Shahin, M. A., and Cheng, L., State of the Art Review of Biocementation by Microbially Induced Calcite Precipitation (MICP) for Soil Stabilization, Geomicrobiology Journal, 34(6), 2016, pp. 524-537.

2. Mujah, D., Shahin, M., and Cheng, L., Performance of Biocemented Sand under Various Environmental Conditions, XVIII Brazilian Conference on Soil Mechanics and Geotechnical Engineering: The Sustainable Future of Brazil goes through our Minas COBRAMSEG 2016, 2016.

3. Muntohar, A.S., Model Studies on the Settlement of Reinforced-embankment with Geotextiles and Plastic-sack Wastes over Soft Soils, Dinamika Teknik Sipil, 12(2), 2015, pp. 101107. 
4. Muntohar, A.S., Hartono, E., Diana, W., and Rahmawati, A., Effect of Cement Replacement with Carbide Waste on the Strength of Stabilized Clay Subgrade, Civil Engineering Dimension, 18(1), 2016, pp. 8-15.

5. Muntohar, A.S., Utilization of Uncontrolled Burnt Rice Husk Ash in Soil Improvement, Civil Engineering Dimension, 4(2), 2002, pp.100-105.

6. Gaafer, M., Bassioni, H., and Mostafa, T., Soil Improvement Techniques, International Journal of Science and Engineering Research, 6(12), 2015, pp. 217-222.

7. Soon, N.W., Lee, L.M., Khun, T.C., and Ling, H.S., Improvements in Engineering Properties of Soils Through Microbial-Induced Calcite Precipitation, KSCE Journal of Civil Engineering, 17(4), 2013, pp. 718-728.

8. Whiffin, V.S., van Paassen, L.A., and Harkes, M.P., Microbial Carbonate Precipitation as a Soil Improvement Technique, Geomicrobiology Journal, 24(5), 2007, pp. 417-423.

9. van Paassen, L.A., Daza, C.M., Staal, M., Sorokin, D.Y., van der Zon, W., and van Loosdrecht, M.C.M., Potential Soil Reinforcement by Biological Denitrification, Ecological Engineering, 36(2), 2010, pp. 168-175.

10. Harkes, M.P., van Paassen, L.A., Booster, J.L., Whiffin, V.S., and van Loosdrecht, M.C.M., Fixation and Distribution of Bacterial Activity in Sand to Induce Carbonate Precipitation for Ground Reinforcement, Ecological Engineering, 36(2), 2010, pp. 112-117.

11. Putra, H., Yasuhara, H., Kinoshita, N., and Hirata, A., Application of Magnesium to Improve Uniform Distribution of Precipitated Minerals in 1-m Column Specimens, Geomechanics Engineering, 12(5), 2017, pp. 803-813.

12. Neupane, D., Yasuhara, H., and Kinoshita, N., Evaluation of Enzyme Mediated Calcite Grouting as a Possible Soil Improvement Technique, in Computer Methods and Recent Advances in Geomechanics, 2015, pp. 1169-1172.

13. Neupane, D., Yasuhara, H., Kinoshita, N., and Putra, H., Distribution of Grout Material within $1 \mathrm{~m}$ Sand Column in Insitu Calcite Precipitation Technique, Soils and Foundation, 55(6), 2015, pp. 1512- 1518.

14. Cheng, L., Cord-Ruwisch, R., and Shahin, M.A., Cementation of Sand Soil by Microbially Induced Calcite Precipitation at Various Degrees of Saturation, Canadian Geotechnical Journal, 50(1), 2013, pp. 81-90.

15. Martinez, B.C., Dejong, J.T., Ginn, T.R., Montoya, G.M., Experimental Optimization of Microbial-Induced Carbonate Precipitation for Soil Improvement, Journal of Geotechnical and Geoenvironmental Engineering, 139(4), 2013, pp. 587-598.

16. van Paassen, L.A., Ghose, R., Van der Linden, T.J.M., Van der Star, W.R.L., and Van Loosdrecht, M.C.M., Quantifying Biomediated Ground Improvement by Ureolysis: Large-Scale Bio- grout Experiment, Journal of Geotechnical and Geoenvironmental Engineering, 136(12), 2010, pp. 1721-1728.

17. DeJong, J.T., Fritzges, M.B., and Nüsslein, K., Microbially Induced Cementation to Control Sand Response to Undrained Shear, Journal of Geotechnical and Geoenvironmental Engineering, 132(11), 2006, pp. 1381-1392.

18. Yasuhara, H., Neupane, D., Hayashi, K., and Okamura, M., Experiments and Predictions of Physical Properties of Sand Cemented by Enzymatically-Induced Carbonate Precipitation, Soils and Foundation, 52(3), 2012, pp. 539-549.

19. Neupane, D., Yasuhara, H., Kinoshita, N., and Unno, T., Applicability of Enzymatic Calcium Carbonate Precipitation as a Soil-Strengthening Technique, Journal of Geotechnical and Geoenvironmental Engineering, 139(12), 2013, pp. 2201-2211.

20. Yasuhara, H., Hayashi, K., and Okamura, M., Evolution in Mechanical and Hydraulic Properties of Calcite-Cemented Sand Mediated by Biocatalyst, in Geo-Frontiers 2011 (C) ASCE 2011, 2011, pp. 3984-3992.

21. Nemati, M., Greene, E.A., and Voordouw, G., Permeability Profile Modification using Bacterially Formed Calcium Carbonate: Comparison with Enzymic Option, Process Biochemistry, 40(2), 2005, pp. 925-933.

22. Putra, H., Yasuhara, H., and Kinoshita, N., Optimum Condition for the Application of Enzyme Mediated Calcite Precipitation Technique as Soil Improvement Method, International Journal on Advances Science, Engineering, and Information Technology, 7(6), 2017, pp. 21452151.

23. Putra, H., Yasuhara, H., and Kinoshita, N., Applicability of Natural Zeolite for NH-Forms Removal in Enzyme-Mediated Calcite Precipitation Technique, Geosciences, 7(3), 2017, p. 61.

24. Yasuhara, H., Neupane, D., Kinoshita, N., Hayashi, K., and Unno, T., Solidification of Sand Soils Induced by Calcium Carbonate Precipitation Utilizing Biocatalyst, Journal of Japan Society of Civil Engineers, Ser. C (Geosphere Engineering), 70(2), 2014, pp. 290-300.

25. Putra, H., Yasuhara, H., Kinoshita, N., and Hirata, A., Optimization of Enzyme-Mediated Calcite Precipitation as a Soil-Improvement Technique: The Effect of Aragonite and Gypsum on the Mechanical Properties of Treated Sand, Crystals, 7(2), 2017, p. 59.

26. Putra, H., Yasuhara, H., Kinoshita, N., Neupane, D., and Lu, C.W., Effect of Magnesium as Substitute Material in Enzyme-Mediated Calcite Precipitation for Soil Improvement Technique, Frontiers in Bioengineering and Biotechnology, 4(37), 2016, pp. 1-8.

27. ASTM, ASTM: $D$ 3080-04, Standard Test Method for Direct Shear Test of Soils Under Consolidated Drained Conditions, ASTM Int. Conshohocken, PA, 04, 2004, pp. 1-7. 